\title{
Sebaran Penyakit Hawar Daun Bakteri di Beberapa Sentra Produksi Bawang Merah di Indonesia
}

\author{
The Spread of Bacterial Leaf Blight Disease at Production Centers of Shallot in Indonesia \\ Asrul $^{1 *}$, Triwidodo Arwiyanto ${ }^{2}$, Bambang Hadisutrisno ${ }^{2}$, dan Jaka Widada ${ }^{2}$ \\ ${ }^{\prime}$ Fakultas Pertanian Universitas Tadulako, Kota Palu \\ Jn. Soekarno Hatta KM 5 Palu Timur, Kota Palu \\ ${ }^{2}$ Fakultas Pertanian Universitas Gadjah Mada \\ Jn. Flora 1, Bulaksumur, Yogyakarta 55281 \\ E-mail: a_ha120372@yahoo.com *Penulis untuk korespondensi
}

\begin{abstract}
The research was aimed to observe the regioned spread of the bacterial leaf blight disease at several shallot plantation centers in Indonesia and the shallot cultivars that can be infected and to identify its pathogens. Determination of the observation site and sampling were conducted in stratified purposive random sampling. The survey was conducted by interviews and observations on the field to the shallot cultivar and the disease symptoms suspected of being infected by the pathogenic bacteria. The samples were identified through a colony morphology observation, Koch postulate test, hypersensitivity reaction test and biochemistry properties test and physiology. The results indicated that the bacterial leaf blight disease had been spread evenly in the whole region of onion plantation in Indonesia, including Cirebon, Tegal, Nganjuk, Bantul and Sigi Regency, with the rate of attacks reached $62.5-100 \%$. This discase infected the cultivar shallots of Bima curut, Bauji, Blue-fields and Palasa. The symptoms of bacterial leaf blight were found in the form of water soaking, leaves, leaf wrinkle, chlorosis and necrosis, died-bud, dawrf growth and plant death. The bacterial isolate found tend to have round, convex, slimy and yellow colonies. The characteristics of colony morphology, symptoms and characteristics of bacterial isolates were similar to the characteristics of of theXanthomonas axonopodis $p v$. allit bacterium, the cause of the leaf blight disease on the shallots.
\end{abstract}

Keywords: Spreading, shallot, bacterial leaf blight, Xanthomonas axonopodis pv. allii

\begin{abstract}
Abstrak
Penelitian ini bertujuan mengetahui daerah sebaran penyakit hawar daun bakteri di beberapa sentra pertanaman bawang merah di Indonesia dan kultivar bawang merah yang dapat diinfeksi, serta mengidentifikasi patogen penyebabnya. Penentuan lokasi pengamatan dan pengambilan sampel dilakukan secara stratified purpossive random sampling. Survei dilakukan dengan cara wawancara dan pengamatan di lapangan (observasi) terhadap kultivar bawang dan gejala penyakit yang terinfeksi oleh bakteri patogen. Sampel diidentifikasi melalui pengamatan morfologi koloni, uji postulat Koch, uji reaksi hipersensitif dan pengujian sifat-sifat biokimia dan fisiologi. Hasil penelitian menunjukkan bahwa penyakit hawar daun bakteri telah tersebar secara merata di seluruh daerah pertanaman bawang merah di Indonesia, yang meliputi Kabupaten Cirebon, Tegal, Nganjuk, Bantul, dan Sigi, dengan tingkat serangan mencapai 62,5-100\%. Penyakit ini menginfeksi bawang merah kultivar Bima curut, Bauji, Biru-sawah, dan Palasa. Gejala hawar daun bakteri yang dijumpai berupa water soaking, terjadi lekukan daun, pengerutan daun, klorosis, nekrosis, mati pucuk, pertumbuhan kerdil, dan kematian. Isolat bakteri yang ditemukan mempunyai bentuk koloni bulat, cembung, berlendir, dan berwarna kuning. Ciri morfologi koloni, gejala dan karakteristik isolat bakteri mirip dengan sifat-sifat bakteri Xanthomonas axonopodis pv. allii penyebab penyakit hawar daun pada bawang bombay.
\end{abstract}

Kata kunci: Sebaran, bawang merah hawar daun bakteri, Xanthomonas axonopodis pv. allii 


\section{Pendahuluan}

Bakteri Xanthomonas axonopodis pv. allii merupakan patogen penyebab penyakit hawar daun yang dapat menyerang dan menginfeksi bawang merah (Allium cepa L. Agregatum group) (Bowen dkk, 1998). Penyakit ini pertama kali dilaporkan pada bawang bombay di Barbados pada tahun 1971 dan patogen penyebabnya diidentifikasi sebagai $X$. axonopodis pv. allii (Robene-Soustrade dkk, 2010). Dari tahun 1990 sampai dengan awal tahun 2000 , penyakit hawar daun telah menyebar ke beberapa negara seperti Amerika Serikat, Brazil, Japan, Republik Afrika Selatan, Venezuela, Pulau Caribbean, Kuba, dan Prancis (Rougmagnac dkk., 2004a).

Hawar daun bakteri pada tanaman bawang merah tergolong penyakit baru di Indonesia dan sangat berbahaya karena di luar negeri serangan patogen ini dapat menimbulkan kehilangan hasil antara 19-100\% (Serfontein, 2001) sehingga berpotensi menjadi kendala utama bagi produksi tanaman tersebut. $\mathrm{Di}$ Indonesia, patogen ini digolongkan ke dalam jenis Organisme Pengganggu Tumbuhan Karantina (OPTK) yang belum terdapat di wilayah Indonesia sehingga masih dikelompokkan sebagai OPTK Kategori A1.

Gejala penyakit hawar daun bakteri berupa kemunculan bercak water soaking (daun layu kebasah-basahan) sepanjang daun, terdapat garis-garis klorosis, kemudian membentuk nekrosis berwarna coklat dan mengering, lalu daun terinfeksi mengalami mati pucuk. Gejala selanjutnya, tanaman tumbuh menjadi kerdil (Schwartz dkk., 2003) dan terjadi penurunan ukuran/berat umbi (Schwartz dan Gent, 2005; Lang dkk., 2007).

Bakteri penyebab penyakit hawar daun dapat ditularkan melalui benih (umbi) sehingga menjadi alat transportasi yang sesuai dengan penyebaran jarak jauh yang efektif dan efisien (Roumagnac dkk., 2004a; Gent dkk., 2005), patogen tidak menimbulkan infeksi pada benih (Nunez dkk, 2002). Benih yang terkontaminasi akan membawa patogen ke area pertanaman baru sehingga dapat menimbulkan ledakan penyakit (Alvarez dkk., 1978). Hasil observasi di beberapa sentra produksi di Indonesia menunjukkan bahwa penyakit hawar daun sudah ada dan telah berkembang di pertanaman bawang merah (Asrul, tidak dipublikasikan).

Keberadaan penyakit hawar daun bakteri di Indonesia dimungkinkan melalui produk impor yang masuk lewat perdagangan benih bawang merah untuk konsumsi. Benih tanaman Allium dapat menjadi media pembawa yang cocok bagi perpindahan bakteri patogen sehingga mengganggu keberlangsungan usaha budidaya pertanian (Roumagnac dkk., 2000; Walcott dkk., 2002). Tingginya pergerakan lalu lintas media pembawa penyakit ini terutama melalui impor dari mancanegara maupun antardaerah (domestik), menyebabkan peluang masuk dan menyebarnya bakteri patogen menjadi semakin besar. Hal ini menimbulkan kekuatiran bahwa bakteri patogen di Indonesia terutama di daerah-daerah sentra produksi menjadi semakin besar.

Pengelolaan penyakit hawar daun bakteri pada bawang merah dapat dilakukan dengan usaha secara preventif. Untuk jangka pendek, pengendalian yang dapat dilaksanakan adalah melakukan pencegahan penyebaran melalui penerapan pembatasan benih bawang merah impor dan penyebaran bakteri patogen ke daerah yang masih bebas patogen secara ketat, terutama oleh pihak Karantina Tumbuhan. Dengan melakukan usaha pencegahan secara dini, diharapkan dapat terhindar dari terjadinya ledakan penyakit dan kerugian hasil produksi bawang merah akibat serangan patogen. Untuk itu, dibutuhkan informasi mengenai daerah sebaran penyakit dan spesies patogen penyebabnya.

Penelitian ini bertujuan mengetahui daerah sebaran penyakit hawar daun bakteri di beberapa sentra pertanaman bawang merah di Indonesia dan kultivar yang diinfeksi, serta mengidentifikasi bakteri patogennya.

\section{Metode Penelitian}

\section{Survei penyakit bakteri di areal pertanaman bawang merah}

Survey dilaksanakan di lima lokasi sentra produksi bawang merah yang tersebar di Indonesia. Penentuan lokasi pengamatan berdasarkan metode Stratified Purpossive Random Sampling, yaitu penentuan lokasi 
pengamatan secara bertingkat. Lokasi terpilih meliputi Kecamatan Losari (Cirebon), Dukuhturi (Tegal), Sukomoro (Nganjuk), Kretek (Bantul), dan Biromaru (Sigi). Penetapan lokasi berdasarkan pertimbangan bahwa daerah tersebut memiliki peluang untuk mewakili kondisi dan permasalahan penyakit hawar daun bakteri karena adanya laporan dari sejumlah petani bahwa pertanaman bawang merah di daerah tersebut terinfeksi penyakit, dengan gejala berupa adanya bercak kebasahbasahan yang tampak seperti ada bekas minyak, daun mengalami layu, mengerut, dan mati pucuk.

Survei dilakukan dengan cara wawancara terhadap petani dan pengamatan di lapangan (observasi), yakni mengamati secara langsung dan mencatat secara sistematik tentang deskripsi tanda dan gejala penyakit yang terinfeksi oleh bakteri patogen, serta mengambil gambar pada tanaman atau lahan pertanian dan lokasi-lokasi atau objek-objek penelitian. Pengamatan juga dilakukan terhadap intensitas penyakit, dihitung menggunakan rumus (Kranz, 1988):

$$
I P=(n \times v) /(N \times Z) \times 100 \%,
$$

\section{Keterangan:}

IP = intensitas penyakit

$\mathrm{n}=$ banyaknya tanaman dengan nilai skor ke $i$

$\mathrm{v}=$ nilai skor ke $i$

$\mathrm{N}=$ jumlah total tanaman yang diamati

$Z=$ nilai skor tertinggi

Skoring penyakit yang digunakan sebagai berikut: 0

$=$ daun sehat, $1=1-25 \%$ daun terserang hawar daun bakteri, $2=26-50 \%, 3=51-75 \%$ dan $4=>75 \%$.

\section{Pengambilan sampel di lapangan}

Sampel tanaman bawang merah yang diambil untuk proses isolasi bakteri patogen berupa tanaman sakit secara utuh yang memperlihatkan gejala, yaitu terdapat kelainan bentuk daun tanaman. Tanah perakaran tanaman digali pada kedalaman $0-25 \mathrm{~cm}$, kemudian tanaman diangkat dan dipaparkan di atas kertas koran selama 15 menit. Tanaman diambil dan dibungkus kertas koran, kemudian dimasukkan ke dalam termos es (cool box) agar tetap stabil hingga dilakukan proses isolasi di laboratorium (Jacobs dkk., 2008). Contoh sampel yang diperoleh segera dibawa ke
Laboratorium Bakteriologi Tumbuhan Fakultas Pertanian Universitas Gadjah Mada Yogyakarta untuk diamati gejala dalamnya dan diisolasi patogennya. Sebelum diamati, sampel disimpan dalam refrigator pada suhu $10^{\circ} \mathrm{C}$ untuk mempertahankan kesegarannya.

\section{Isolasi bakteri patogen di laboratorium}

Isolasi bakteri patogen dilakukan terhadap 150 sampel tanaman bawang merah sakit yang diambil dari lima Kabupaten, menggunakan media buatan Yeast Peptone Glucose Agar (YPGA). Tanaman bawang merah (daun) yang sakit dibersihkan dengan cara dicuci hingga bersih menggunakan air mengalir. Daun dipotong-potong kecil (dengan skalpel) dan direndam dalam larutan alkohol $70 \%$ selama 1 menit, kemudian potongan daun dicelupkan ke dalam air steril selama 30 detik, dan dipindahkan di atas kertas filter steril untuk dikeringkan. Selanjutnya, potongan daun dimasukkan dalam $5 \mathrm{ml}$ air steril dan digojog selama 3-5 menit, air gojokan digoreskan menggunakan jarum ose pada permukaan medium YPGA dalam cawan petri. Komposisi medium YPGA terdiri atas $3 \mathrm{~g}$ ekstrak yeast, $10 \mathrm{~g}$ pepton, $7 \mathrm{~g}$ glukosa dan $15 \mathrm{~g}$ agar dalam aquadest steril $1000 \mathrm{ml}$. Cawan petri diinkubasi selama 96 jam pada suhu $28^{\circ} \mathrm{C}$. Koloni yang tumbuh diambil dengan ose steril kemudian dipindahkan ke medium YPG cair sebagai stockculture.

Peremajaan isolat dilakukan dengan menumbuhkan kembali seratus lima puluh isolat bakteri dari stok kultur koleksi ke medium YPGA, yakni mencelupkan satu ose dari stok kultur cair kemudian digoreskan pada medium YPGA. Pengambilan satu ose dari stok kultur cair dilakukan secara aseptik, kemudian digoreskan ke medium YPGA dalam cawan petri. Cawan petri kemudian diinkubasi pada suhu ruang selama 24-72 jam hingga diperoleh koloni tunggal. Koloni tunggal yang diperoleh dari setiap isolat bakteri, diinokulasikan pada medium YPGA miring, kemudian diinkubasi pada suhu ruang selama 72 jam. Bakteri yang tumbuh setelah 24-72 jam tersebut dapat digunakan untuk pengujian selanjutnya. Kultur bakteri tersebut berperan sebagai working culture. 


\section{Uji hipersensitif}

Uji reaksi hipersensitif dilakukan terhadap 150 isolat bakteri yang ditemukan berasosiasi dengan bawang merah sakit. Uji hipersensitif dilakukan menurut metode Kawamoto dan Lorbeer (1972) yang telah dimodifikasi, yakni biakan murni bakteri ditumbuhkan dan diperbanyak selama 48 jam di atas media YPGA miring, kemudian dibuat suspensi dengan konsentrasi $10^{8} \mathrm{cfu} / \mathrm{ml}$. Suspensi sebanyak $1 \mathrm{ml} /$ daun diinjeksikan ke dalam ruang interseluler daun muda tanaman tembakau (Nicotiana tabacum) umur 1 bulan dengan menggunakan hypodermic syringe (tanpa jarum). Tanaman yang telah diinjeksi suspensi bakteri diinkubasi pada suhu $27-32^{\circ} \mathrm{C}$. Timbulnya gejala berupa water soaking dilanjutkan dengan pemunculan bercak kecil atau nekrosis pada daerah suntikan di daun yang terjadi dalam waktu 24-48 jam menunjukkan terjadinya reaksi positif. Hasil yang positif pada uji reaksi hipersensitif menunjukkan bahwa bakteri tersebut merupakan bakteri tumbuhan dan patut diduga sebagai bakteri patogen (Duveiller dkk., 1997).

\section{Uji patogenesitas di rumah kasa}

Untuk mengetahui kemampuan bakteri patogen dalam menimbulkan penyakit pada tanaman (patogenesitas), dibuktikan dengan uji postulat Koch pada beberapa isolat bakteri yang telah ditemukan. Kultur isolat bakteri ditumbuhkan dan diperbanyak pada submedium YPGA. Biakan bakteri diinkubasikan pada suhu ruang selama $72 \mathrm{jam}$, kemudian, disuspensikan dalam air steril sebagai inokulum bakteri dengan kerapatan $10^{8} \mathrm{cfu} / \mathrm{ml}$.

Inokulasi pada daun dilakukan dengan metode Nunez dkk., (2002) yakni daun tanaman yang sehat berumur dua minggu dilukai dengan jarum steril pada bagian ujung daun, kemudian disemprot dengan suspensi bakteri sebanyak $10 \mathrm{ml} /$ tanaman menggunakan hand sprayer. Setelah diinokulasi, tanaman ditempatkan dalam rumah kasa. Sebagai kontrol, daun tanaman bawang merah diinokulasi dengan $0,5 \mathrm{ml}$ air suling steril. Pengamatan terhadap hasil inokulasi dilakukan setiap hari dari tanaman diinokulasi sampai timbul gejala (masa inkubasi). Gejala serangan yang diamati saat pertama kali terbentuknya hawar daun adalah awal terjadinya infeksi.

Tahap selanjutnya, isolat bakteri diisolasi kembali (reisolasi) dari tanaman yang terinfeksi dan telah menimbulkan gejala penyakit (Agrios, 2005). Lebih lanjut, isolat tersebut dimurnikan pada subbiakan YPGA dan koloni tunggal yang telah murni disimpan dalam larutan gliserol $15 \%$ atau air steril pada suhu $4^{\circ} \mathrm{C}$ untuk pengujian selanjutnya.

Pengujian sifat-sifat biokimia dan fisiologi isolat bakteri

Pengujian sifat-sifat biokimia dan fisiologi isolat bakteri yang ditemukan terdiri atas uji reaksi gram, kebutuhan oksigen (OF), oksidasi, urease, levan, pembentukan pigmen fluoresen, dehidrolisis arginin, produksi indol, hidrolisis pati dan gelatin, katalase, reduksi nitrat, tween 80 , sumber karbon, pengaruh suhu, $\mathrm{pH}$, dan kandugan $\mathrm{NaCl}$. Hasil pengujian sifat-sifat isolat bakteri yang ditemukan tersebut, selanjutnya dibandingkan dengan sifat-sifat bakteri $X$. axonopodis pv. allii yang telah dideskripsikan oleh Kadota dkk., (2000); Schaad dkk., (2001) dan Roumagnac dkk., (2004b).

\section{Hasil dan Pembahasan}

\section{IdentifikasiXanthomonasaxonopodis pv. allii}

Berdasarkan hasil pengamatan secara makroskopis, semua isolat bakteri yang ditumbuhkan di atas medium YPGA, mempunyai bentuk morfologi koloni yang bervariasi. Hasil isolasi diperoleh koloni bakteri berbentuk bulat teratur hingga tidak teratur, tepi rata hingga tidak beraturan, berlendir (mucoid), halus / lembut, tidak tembus cahaya, mengkilat, permukaan cembung, dan berwarna kuning hingga kuning keputihan (Gambar 1). Bentuk morfologi koloni isolat bakteri ini memiliki kemiripan dengan bentuk koloni $X$. axonopodis pv. allii yang dilaporkan oleh Rougmagnac dkk., (2004b), yakni berbentuk bulat, berwarna kuning pada media YPGA, cembung dan berlendir.

Hasil pengujian reaksi hipersensitif menunjukkan isolat bakteri yang diujikan menimbulkan gejala water soaking (daun layu 
kebasah-basahan) pada permukaan jaringan daun tembakau setelah 2 hari, kemudian berkembang membentuk gejala nekrosis berwarna coklat setelah 5 hari (Gambar 1c). Menurut Kerr dan Gibb (1997), bila bakteri yang diuji berupa bakteri patogen maka akan terjadi nekrosis dan klorosis pada tanaman tembakau. Hal ini berarti terdapat hubungan yang kompatibel antara patogen dan daun tembakau. Dengan demikian, isolat bakteri tersebut merupakan bakteri patogen pada tumbuhan.

Pada uji postulat Koch, tampak gejala di lapangan mempunyai kesamaan dengan gejala yang muncul sebagai hasil inokulasi di rumah kasa (Gambar 2 dan 3). Gejala yang timbul berupa daun layu kebasah-basahan (water soaking), daun mengerut, terjadi lekukan daun tepat pada bercak kebasahan tersebut, klorosis dan nekrosis (Bowen dkk., 1998). Menurut Agrios (2005), uji postulat Koch dikatakan berhasil jika inokulum yang diinokulasikan ke tanaman menimbulkan gejala yang sama dengan awal tanaman yang sakit. Hal ini membuktikan bahwa bakteri patogen penyebab penyakit hawar daun pada tanaman bawang merah adalah Xanthomonas axonopodispv. allii.

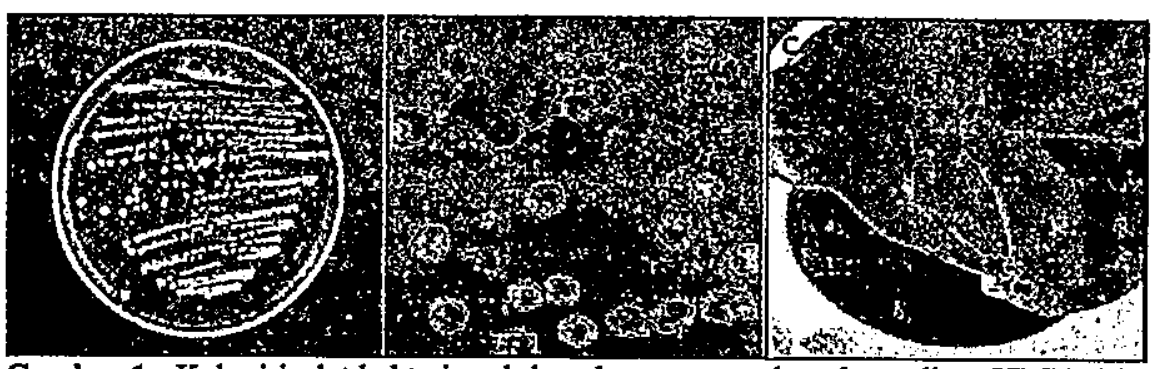

Gambar 1. Koloni isolat bakteri asal daun bawang merah pada medium YPGA (ab); reaksi hipersensitif isolat bakteri tersebut pada daun tembakau (c).

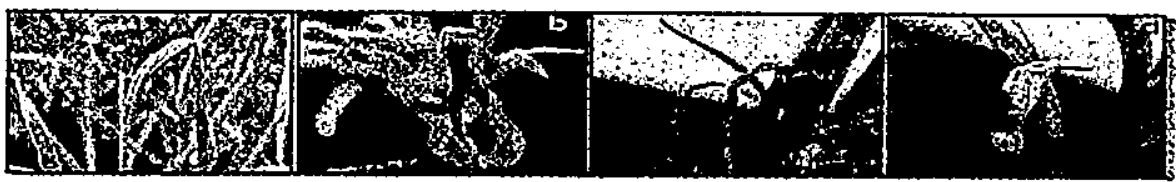

Gambar 2. Gejala penyakit hawar daun bakteri di lapang (a); dan di rumah kasa (bod)



Gambar 3. Isolat baktcri bereaksi positif pada uji gram scbagai gram negatif (a); pada uji OF menunjukkan reaksi positif pada kondisi aerob (b); isolat bakteri bereaksi negatif pada uji oksidase (c); pada uji katalasc, isolat bakteri bercaksi positif (d); pada medium Christensen's isolat bakteri menunjukkan reaksi negatif pada uji urease (c); uji reduksi nitrat pada isolat bakteri bercaksi negati (f). 
Berdasarkan pengujian sifat-sifat biokimia dan fisiologi, isolat bakteri yang diuji menunjukkan reaksi gram negatif. Selain itu, isolat-isolat tersebut bereaksi negatif terhadap uji oksidasi, urease, reduksi nitrat, pigmen fluoresen, arginin, dan produksi indol. Isolat bakteri uji bereaksi positif terhadap uji katalase, hidrolisis tween 80 dan membentuk levan dari sukrosa. Isolat bakteri tidak mampu beraktivitas dalam kondisi anaerob sehingga bersifat oksidatif (aerob) (Gambar 3).

Meskipun pengujian ini masih bersifat konvensional tetapi sudah cukup memadai untuk mengidentifikasi bakteri, sehingga dapat diestimasi bahwa isolat yang diuji telah mendekati sifat-sifat spesies bakteri $X$. axonopodis pv allii yang dideskripsikan oleh Kadota dkk., (2000); Schaad dkk., (2001) dan Roumagnac dkk., (2004b) karena ada kemiripan sifat di antara keduanya.

\section{Sebaran penyakit hawar daun bakteri}

Data daerah sebaran, varietas bawang merah dan intensitas penyakit hawar daun bakteri disajikan pada Tabel 1 .

Berdasarkan kultivar bawang merah, bakteri $X$. axonopodis pv, allii ternyata dapat menyebabkan penyakit hawar daun dan menginfeksi semua kultivar bawang merah yang ditanam, baik kultivar Bima curut, Bauji, Biru sawah maupun Palasa. Intensitas serangan pada berbagai kultivar bawang merah mempunyai variasi relatif sempit, yakni kultivar Bauji dan Palasa mempunyai intensitas serangan paling tinggi mencapai $100 \%$, sedangkan kultivar Bima curut dan Biru sawah masing-masing mencapai 95,58 dan $91,66 \%$. Rendahnya variasi kultivar bawang merah yang terserang bakteri patogen disebabkan oleh jumlah kultivar yang diamati hanya sedikit yakni empat kultivar, sesuai dengan jumlah kultivar yang ditemukan selama pengamatan di lapangan. Secara umum, tingginya intensitas serangan penyakit hawar daun bakteri pada seluruh kultivar bawang merah yang ditanam menunjukkan ke empat kultivar tersebut sangat peka dan rentan terhadap infeksi penyakit hawar daun bakteri. Sampai saat ini keempat kultivar tidak memiliki data ketahanan terhadap penyakit hawar daun sehingga dikuatirkan dapat memicu tingginya tingkat serangan di seluruh daerah pertanaman bawang merah. Hal ini menandakan bahwa sampai saat ini belum ada kultivar bawang merah yang resisten terhadap bakteri $X$. axonopodis pv. allii di Indonesia.

Kerentanan kultivar bawang merah ini diduga berkaitan dengan ketahanan tanaman bawang merah dalam merespons serangan bakteri patogen. Menurut Agrios (2005), kultivar tanaman yang rentan lebih disebabkan karena tidak mempunyai gen ketahanan yang efektif untuk mengatasi gen patogen tersebut. Gen-gen ini mengendalikan senyawa-senyawa kimia dan proses fisiologi yang memberi kontribusi pada tanaman terutama dalam hal ketersediaan potensial genetik dalam mengembangkan satu atau lebih sifat-sifat morfologi atau fisiologi untuk ketahanan tanaman terhadap penyakit.

Keberadaan penyakit hawar daun di suatu daerah pertanaman bawang merah dapat diketahui dengan adanya intensitas serangan patogen yang ditandai dengan munculnya gejala. Gejala infeksi penyakit hawar daun bakteri (leaf blight) berupa daun layu kebasahbasahan (water soaking) pada sebagian daun, berwarna hijau pucat, membentuk lekukan daun, dan pengerutan daun. Pada daun terdapat bercak nekrosis kecil di permukaan daun yang mengerut, lambat laun bercak menyatu membentuk bercak yang lebih besar, berwarna coklat, mengering, dan mati (Gambar 4). Gejala ini telah ditemukan di seluruh lokasi pertanaman bawang merah yang sakit dengan intensitas serangan berkisar antara 62,50$100 \%$. Data ini menunjukkan bahwa $X$. axonopodis pv.allii penyebab penyakit hawar daun bakteri telah menyerang tanaman bawang merah dan tersebar secara merata di lima kabupaten yang disurvei, yakni Cirebon, Tegal, Nganjuk, Bantul, dan Sigi (Sulawesi Tengah). Oleh karena itu, penyakit hawar daun perlu mendapat perhatian serius dan harus diwaspadai karena penyakit tersebut dapat menurunkan produksi secara ekonomi berupa penurman berat umbi bawang merah (Gent dkk., 2005).

Berdasarkan daerah sebaran penyakit hawar daun, terungkap bahwa penyakit yang disebabkan oleh bakteri $X$. axonopodis pv. allii telah berada di seluruh wilayah sentra produksi 
bawang merah di Indonesia. Keberadaan penyakit ini masuk ke wilayah Indonesia melalui benih bawang merah impor yang berasal dari negera-negara seperti India, Thailand, Philipina, Vietnam, China, Malaysia, Netherlands, USA, dan Australia (BPS, 2012). Berdasarkan informasi dari petani (hasil wawancara), penggunaan umbi impor, seperti kultivar Super Philip, untuk memenuhi kebutuhan bibit yang dipersiapkan bagi penanaman di musim kemarau karena kultivar tersebut lebih tahan kering dan produksinya lebih tinggi. Hal ini memberi peluang masuknya organisme pengganggu tanaman yang belum terdapat di Indonesia, terutama organisme patogen yang dapat terbawa bersama benih karena benih bawang merah impor untuk tujuan konsumsi tidak menjalani proses sertifikasi (Basuki, 2009). Menurut Kusmana dkk., (2009), benih bawang merah yang diimpor $\mathrm{ke}$ wilayah Indonesia untuk konsumsi memiliki potensi menularkan patogen karena benih tersebut tidak dihasilkan lewat proses sertifikasi benih. Bakteri $X$. axonopodis pv. allii merupakan bakteri patogen bawang bombay yang penyebarannya dapat terbawa bersama benih atau bahan pembiakan vegetatif lainnya (Roumagnac dkk, 2004a) sehingga memiliki potensi merusak sangat besar (Nowbuth dkk., 2005). Hasil penelitian Bowen dkk. (1998) menunjukkan bahwa selain menyerang bawang bombay, bakteri $X$. axonopodis pv. allii juga dapat menginfeksi bawang merah, bawang putih, dan bawang daun. Bila benih impor yang telah terkontaminasi patogen ditanam di lahan pertanian, patogen yang terbawa bersama benih akan terinfestasi ke dalam lahan tersebut dan menyebabkan terjadinya kontaminasi tanah dan tanaman sehingga menjadi sumber inokulum bagi pertanaman bawang merah sehat berikutnya, terutama bawang merah lokal. Lahan pertanian bekas pertanaman bawang merah sakit ini akan menjadi area yang sangat rawan terhadap infeksi $X$ axonopodis pv. allii selama periode tertentu. Schaad dan White (1974) melaporkan bahwa bakteri Xanthomonas dapat bertahan hidup dan berkembang di dalam tanah selama 2 tahun bila terdapat sisa-sisa tanaman inang. Infeksi tanaman di lahan pertanaman dapat terjadi melalui tanah yang terinfestasi oleh
bakteriX. campestris (axonopodis) (Lopez dkk., 1999).

Di Indonesia, keberadaan bakteri ini di selurub lokasi pengamatan menunjukkan bahwa sebaran bakteri patogen tersebut meliputi daerah yang sangat luas. Bakteri tidak hanya terdapat di pulau Jawa seperti di Kabupaten Cirebon, Tegal, Nganjuk, dan Bantul, tetapi juga ditemukan di luar pulau Jawa yakni Kabupaten Sigi (Sulawesi Tengah). Penyebaran bakteri patogen secara meluas ke daerah lain disebabkan adanya perdagangan benih bawang merah antardaerah/pulau. Diduga benih yang telah beredar dan diperdagangkan ke luar daerah/pulau berasal dari benih asalan (lokal) yang telah terinfeksi bakteri patogen. Berdasarkan wawancara petani yang dilakukan selama survei, diperoleh informasi bahwa benih yang ditanam berasal dari benih yang telah digunakan dari penanaman sebelumnya pada lahan sendiri, dari lahan sekitarnya, atau membeli di pasar tradisional. Sementara penyakit hawar daun bakteri banyak dijumpai menginfeksi sebagian besar lahan pertanaman bawang merah varietas Bima curut, Baijo, Biru dan Palasa, dengan intensitas penyakit yang cukup berat. Selain itu, benih yang dijual bebas dari pasar kemungkinan telah terinfeksi dan tercemar patogen dari tempat asal benih itu diperoleh. Dengan demikian, tidak ada jaminan bahwa benih yang digunakan selama ini oleh petani untuk keperluan budidaya merupakan benih yang terbebas dari kontaminasi patogen. Tampaknya petani dalam memilih bawang merah untuk budidaya hanya berdasarkan pada kesesuaian kultivar yang dapat berproduksi tinggi, sementara aspek ketahanan kultivar terhadap penyakit dan kesesuaian musim belum dapat meyakinkan petani. Bawang merah Super Philip merupakan kultivar yang sangat cocok ditanam di musim kemarau dan mampu berproduksi tinggi, akan tetapi sebagian besar petani terutama di daerah Nganjuk dan Bantul tetap menanam kultivar tersebut meskipun di musim hujan (Wiyatiningsih dkk., 2009). Hal ini menyebabkan keberadaan penyakit selalu ada sepanjang musim dengan tingkat serangan cukup tinggi. Menurut Humeau dkk., (2006), penyebaran dan keberadaan penyakit hawar daun di seluruh dunia berkaitan dengan status 
bakteri $X$. axonopodis pv. allii penyebab penyakit tersebut yang terbawa benih dengan meningkatnya perdagangan internasional dan aktivitas manusia. Patogen ini sangat berbahaya karena selain berpotensi menimbulkan epidemi, juga karena bakteri ini dapat ditularkan melalui benih sehingga berperan penting dalam penyebaran penyakit. Bakteri $X$. axonopodis pv. allii yang berasosiasi dengan benih dapat bertahan hidup hingga 10 tahun pada kondisi penyimpanan $4^{\circ} \mathrm{C}$ (Robene-Soustrade dkk., 2010). Penyebaran bakteri patogen dapat juga terbawa melalui tanah, peralatan pertanian, atau alat angkut yang telah terkontaminasi patogen ke daerah lain melalui pergerakan aktivitas manusia (Goto, 1992). Berdasarkan daerah sebaran ini pula dapat dikatakan bahwa $X$. axonopodis pv. allii bersifat kosmopolit karena bakteri tersebut ditemukan pada berbagai lokasi pertanaman bawang merah.

Tabel 1. Persentase serangan penyakit hawar daun bakteri dan varietas bawang merah di berbagai lokasi pengamatan.

\begin{tabular}{lcc}
\hline $\begin{array}{c}\text { Lokasi Pengamatan } \\
\text { (Kabupaten / Kecamatan) }\end{array}$ & Kultivar Bawang Merah & Intensitas Serangan (\%) \\
\hline Cirebon/Losari & Bima curut & $70,00-95,45$ \\
Tegal/Kalirahayu & Bima curut & $79,16-95,58$ \\
Nganjuk/Sukomoro & Bauji & $77,50-100,00$ \\
Bantul/Kretek & Biru sawah & $62,50-91,66$ \\
Sigi/Biromaru & Palasa & $81,25-100,00$ \\
\hline
\end{tabular}



Gambar 4. Gejala penyakit hawar daun bakteri pada bawang merah di lapang (abc).

\section{Simpulan}

Penyakit hawar daun bakteri ditemukan telah menginfeksi dan telah tersebar secara merata di seluruh daerah pertanaman (sentra produksi) bawang merah di Indonesia, yang meliputi Kabupaten Cirebon, Tegal, Nganjuk, Bantul, dan Sigi, dengan tingkat serangan mencapai $62,5-100 \%$. Penyakit ini menginfeksi bawang merah kultivar Bima curut, Bauji, Biru-sawah dan Palasa. Keberadaan penyakit hawar daun bakteri yang disebabkan oleh Xanthomonas axonopodis pv. allii di daerah pertanaman bawang merah telah terdeteksi berdasarkan gejala di lapangan, rumah kasa, dan uji biokimia dan fisiologis.

\section{Ucapan Terima Kasih}

Penelitian ini merupakan sebagian dari hasil Penelitian Pascasarjana yang mendapat dukungan dana dari Lembaga Penelitian Universitas Gadjah Mada berdasarkan Surat Perjanjian Kerjasama Nomor: LPPMUGM/729/BID.I/2012 Tanggal 5 Maret 2012. Penulis mengucapkan terima kasih atas bantuan dana dan kerja samanya.

\section{Daftar Pustaka}

Alvarez, A.M., Buddenhagen, I.W, Buddenhagen, E.S. dan Domen, H.Y. 1978. Bacterial blight of onion, a new disease caused by Xanthomonas sp. Phytopathology, 68: 1132-1136. 
Agrios, N.G. 2005. Plant Pathology-Fifth Edition. Departemen of Plant Pathology. University of Florida. United States of America. 67-93 pp

Badan Pusat Statistik. 2012. Statistik Indonesia. Jakarta: Badan Pusat Statistik.

Basuki, R.S. 2009. Analisis tingkat preferensi petani Brebes terhadap karakteristik hasil dan kualitas bawang merah varietas Iokal asal dataran medium dan tinggi. Jurnal Hortikultura, 19 (4): 475-483.

Bowen, P., Gibbs, H. dan O'Garro, L.W. 1998. Garlic, chives, shallot and leck are alternative host to Xanthomonas campestris, the pathogen of leaf blight of onion. Proceedings 7 th International Congress Plant Pathology, Edinburgh, Scolland.

Cook, A.A. dan Stall, R.E. 1977. Effect of Water Soaking on Response to Xanthomonas vesicatoria in Pcpper Leaves. Phytopathology, 67: 11011103.

Duvciller, E., Bragard, C., Rudolph, X. dan Fucikovsky, L. 1997. General Concepts and Methodes for the Identification of Pathogenic Bacteria of Wheat. In: Duveiller, E., Fucikovsky, L. and Rudolph, $\mathrm{K}$. The Bacterial Diseases of Wheat Concepts and Methods of Disease Management, CIMMYT, Mexico.

Gent, D.H., Lang, J.M. dan Schwartz, H.F. 2005 c. Epiphytic survival of Xanthomonas axonopodis pv, allii and $X$. axonopodis pv. phaseoli on Ieguminous host and onion. Plant Dis., 89: 558-564.

Goto, M. 1992. Fundamental of Bacterial Plant Pathology. Academic Press, Inc. San Diego New YorkBoston.

Humeau, L., Roumagnac, P., Picard, Y., RobeneSoustrade, I., Chiroleu, F., Gagnevin, L. dan Pruvost, O. 2006. Quantitative and molecular epidemiology of bacterial blight of onion in seed production fields. Phytopathology, 96: 1345-1354.

Kadota, I., Uehara, K., Shinohara, H. dan Nishiyama, K. 2000. Bacterial blight of welsh onion : a new disease caused by Xanthomonas campestris pv. alli pv. nov.Journal Gen. Plant Pathology, 66: $310-315$

Kawamoto, S.O. dan Lorbeer, J.W. 1972. Multiplication of Pseudomonas cepacia in onion leaves. Phytopathology, 62: 1263-1265.

Kerr, A. dan Gibb, K. 1997. Bactcria and Phytoplasma as Plant Parasites. In : Plant Pathogens and Plant Disease. J.F. Brown and H.J. Ogle (eds), Australian Plant Pathology Society, Armidale, 86-103 p.
Kranz, J. 1988. Measuring Plant Disease. In: Kranz, J.dan J. Rotem (eds), Experimental Techniques in Plant Disease Epidemiology, 35-50.

Kusmana, R., Basuki, S. dan Kurniawan, H. 2009. Uji adaptasi lima varietas bawang merah asal dataran tinggi dan medium pada ekosistem dataran rendah Brebes. Jurnal Hortikultura, 19 (3): 281-286.

Lang, J.M., Gent, D.H. dan Schwartz, H.F. 2007. Management of Xanthomonas leaf blight of onion with bacteriopaghes and a plant activator. Plant Disease, 91: 871-878.

Lopez, N.I., Haedo, A.S. dan Mandez, B.S. 1999. Evaluation of Xanthomonas campestris survival in a soil microcosm system. International Microbiology, 2: 111-114.

Nowbuth, P., Khitto, G. dan Venkatasamy, S. 2005. Phenotypic diversity of Xanthomonas strains isolated from onion blight using metabolic fingerprinting. Food and Agricultural Research Councll, Reduit, Mairitus, 375-381.

Nunez, J.J., Gilbertson, R.L., Meng, X. dan Davis, R.M. 2002. First Report of Xanthomonas Leaf Blight of Onion in California. Plant Disease, 86 (3): 137-142.

Robene-Soustrade, I.R., Legrand, D., Gagnevin, L., Chiroleu, F., Laurent, A dan Pruvost, $O$. 2010. Multiplex nested PCR for detcction of Xanthomonas axonopodis pv. allii from onion seeds. Applied and Enviromental Microbiology, 76 (9): 2697-2703.

Roumagnac, P., Gagnevin, L. dan Pruvost, O. 2000. Detection of xanthomonas sp., the causal agent of onion bacterial blight, in onion seed using a newly developed semi-selektive isolation medium. European Jotmal of Plant Pathology, 106: 867-877.

Roumagnac, P., Pruvost, O., Chiroleu, F. dan Hughes, G. 2004a. Spatial and Temporal analyses of bacterial oof onion caused by Xanthomopnas axonopodis pv. allit. Phytopathology, 94: 138-146.

Roumagnac, P., Gagnevin, L., Gardan, L., Sutra, L., Manccau, C., Dickstein, E.R., Jones, J.B., Rott, P. dan Pruvost, O. 2004b. Polyphasic characterization of Xanthomonas isolated from onion, garlic and welsh onion (Allitum spp) and their relatedness to different Xanthomonas specics. International Journal of Systematic and Evolutionary Microbiology, 54: $15-24$

Schwartz, H.F., Otto, K.L. dan Gent, D.H. 2003. Relation of temperature and rainfall to development of Xanthomonas and Pantoea leaf blights of onion in Colorado. Plant Disease, 87: 11-14. 


\section{Penyakit Hawar Daun Bakteri}

Schvartz, H.F. dan Gent, D.H. 2005. Diseases: Xanthomonas Leaf Blight of Onion. Gardening Series No. 2.951. Colorado State University, USA.

Schaad, N.W., Jones, J.B. dan Lacy, G.H. 2001. Xanthomonas. In: Laboratory guide for identification of plant pathogenic bacteria. Third Edition N. W. Schaad, J. B. Jones and W. Chun, APS Press, 3340 Pilot Knob Road, St. Paul, MN, 55121-2097, USA.

Schaad, N.W. dan White, W.C. 1974. Survival of Xanthomonas campestris in soil. Phytopathology, 64: 1518-1520.
Serfontein, J.J. 2001. Xanthomonas blight of onion in South Africa. Plant Disease, 85 (4): 442-442.

Walcott, R.R., Gitaitis, R.D., Castro, A.C., Sanders, F.H. dan Diaz-Perez, J.C. 2002. Natural infestation of onion seed by Pantoea ananatis causal agent of center rot. Plant Disease, 86: 106-111.

Wiyatiningsih, S., Wibowo, A. dan Triwahyu, E.P. 2009. Keparahan penyakit moler pada enam kulivar bawan merah karena infeksi Fusarium oxysporum f.sp. cepae di tiga daerah sentra produksi. Seminar Nasional. Aksclerasi Pengembangan Teknologi Pertanian Dalam Mendukung Revitalisasi Pcrtanian. Surabaya. 